\title{
Pemahaman Siswa Tentang Entrepreneurship dan Gaya Hidup Konsumtif dengan Komitmen Cinta Croduk Dalam Negeri
}

\author{
Nurita. ${ }^{1}$ Pudjiastuti, $\mathrm{SR}^{1}$ dan Suidat ${ }^{1}$ \\ ${ }^{1}$ Program, Magister PPKn STKIP Arrahmaniyah Depok, Indonesia
}

\begin{abstract}
Abstrak-Penelitian ini bertujuan untuk memperoleh data empiris mengenai: hubungan pemahaman siswa tentang Entrepreneurship dan Gaya Hidup Konsumtif dengan Komitemn Cinta Produk dalam Negeri. Penelitian ini dilaksanakan mulai Juli sampai September 2020. Metode yang digunakan dalam penelitian ini adalah metode Survey dengan pendekatan korelasional. Populasi penelitian adalah siswa SMK AlBasyariah jurusan TJK kelas XI, jumlah populasinya 106 sisiwa. Instrumen yang digunakan adalah tes untuk variabel X1 ( Pemahaman siswa tentang entreprenuership), untuk variabel X2( Gaya hidup konsumtif) menggunakan angket skala prilaku, dan untuk varuabel Y ( komitmen cinta produk dalam negeri)

menggunakan angket skala sikap. Teknis analisis data menggunakan analisis regresi berganda. Terdapat hubungan positif yang sangat signifikan antara pemahaman siswa tentang entrepreuership dan gaya hidup konsumtif bersama-sama dengan pelestarian budaya bangsa dengan koefisien korelasi $\left(\mathrm{R}_{\mathrm{y} 12}\right)$ sebesar 0,9614 $(\alpha=0,05)$ didukung dengan persamaan regresi ganda antaar kedua variabel bebas dengan variabel terikat adalah $\hat{\mathrm{Y}}=9,033+(-0,0826) \mathrm{X}_{1}-0,092151 \mathrm{X}_{2}$. Kontribusi pemahaman siswa tentang entrepreuership dan gaya hidup konsumtif dengan komitmen cinta produk dalam negeri sebesar $92,42 \%\left(\mathrm{R}_{\mathrm{y} 12}\right)$.
\end{abstract}

\section{Kata kunci:}

Entrepreneurship,

Gaya Hidup,

Komitmen

(C)2021 JCC. All rights reserved

\section{Histori:}

Dikirim: 28 Juni 2021

Direvisi: 13 September 2021

Diterima: 30 September 2021

Online: 30 September 2021

\section{Identitas Artikel:}

Nurita, N., Pudjiastuti, S.R., \& Suidat, S. (2021). Pemahaman Siswa Tentang Entrepreneurship dan Gaya Hidup Konsumtif dengan Komitmen Cinta Croduk Dalam Negeri. Jurnal Citizenship Virtues, 1(2), 167-173.

\section{PENDAHULUAN}

Entrepreneur menjadi tema besar dan menarik dibahas bukan hanya dalam ranah ekonomi melainkan dalam ranah kehidupan sosial, Kesehatan, politik, pemerintahan, bahkan pendidikan. Entrepreneurship dalam dunia pendidikan mencangkup peserta didik, proses pembelajaran dan hasil belajaran. Entrepreneurship dijadikan sebagai salah satu kompetensi yang harus dicapai dalam Standar Kompetensi Lulusan, telah teruji mengandung nilai-nilai kebaikan yang peserta didik memilki nilai-nilai kebaikan yang terkandung di dalamnya visi dan misi yang jelas, kreatif dan inovatif, berani menanggung resiko, berjiwa kompetisi, mampu melihat dan menciptakan peluang, cepat tanggap dan gerak cepat, berjiwa sosial dan menjadi dermawan. Dalam arti yang lebih luas bahwa pendidikan kewirausahaan adalah pertolongan untuk membelajarkan manusia

\footnotetext{
${ }^{1}$ *Corresponding author.

E-mail: Nuritasayyidah@gmail.com
} 
Indonesia sehingga mereka memiliki kekuatan pribadi yang dinamis dan kreatif sesuai dengan kepribadian bangsa Indonesia yang berdasarkan pancasila.

Rendahnya budaya entrepreneurship disebabkan oleh beberapa persoalan diantaranya belum optimalnya kebijakan pemerintah dan implementasinya dalam menanamkan jiwa kewirausahaan, kurangnya fasilitas yang dapat mendukung kegiatan kewirausahaan bagi generasi muda, dan masih rendahnya sinergitas antar pemangku kepentingan, maka diperlukan penanaman jiwa kewirausahaan berbasis digital. Dengan budaya entrepreneurship, maka akan muncul inovasi untuk berlomba menciptakan ide-ide baru yang mampu memiliki pemikiran inovatif (innovative), menciptakan terobosan baru yang kreatif (breakthrough) dan berani menanggung resiko (risk taking).(Pudjiastuti:2019)

Menurut Pinchot (Usman:2009), entrepreneurship merupakan kemampuan untuk menginternalisasikan bakat, rekayasa, dan peluang yang ada sementara entrepreneur adalah orang yang berani mengambil resiko, inovatif, kreatif, pantang menyerah dan mampu menyiasati peluang secara tepat. (Riayanti:2003) mengemukakan pendapat bahwa entrepreneurship adalah kemampuan seorang pengusaha dalam menciptakan kerja untuk orang lain dengan cara mendirikan, mengembangkan dan melembagakan perusahaan miliknya, siap mengambil resiko serta kreatif mengunakan potensi-potensi yang dimiliki dalam mengembangkan produksinya.

Sutisna (2008) menjelaskan bahwa gaya hidup masyarakat akan berbeda dengan masyarakat yang lainnya, bahkan dari masa ke masa gaya hidup suatu individu dan kelompok masyarakat tertentu akan bergerak dinamis. Akan tetapi, gaya hidup tidak mudah berubah, bisa jadi dalam masa tertentu relative permanen. (Setiadi:2010) Gaya hidup pada dasarnya merupakan suatu perilaku yang mencerminkan masalah apa yang sebenarnya ada di dalam alam pikir pelanggan yang cenderung berbaur dengan berbagai hal yang terkait dengan masalah emosi dan psikologis konsumen.

Menurut Aprilia \& Hartono (2013) perilaku konsumtif adalah perilaku individu yang dipengaruhi oleh faktor-faktor sosiologis dalam kehidupannya yang ditujukkan untuk mengkonsumsi secara berlebihan atau pemborosan dan tidak terencana terhadap jasa dan barang yang kurang atau bahkan tidak diperlukan. Kartodiharjo (1995) menyatakan pola hidup konsumtif dapat dipengaruhi oleh factor budaya, demikian juga dengan mode dengan cepat dapat menular terutama pada produk-produk tertentu. Di samping itu sikap seseorang seperti orang tidak mau ketinggalan dari 10 temannya atau penyakit kultural yang disebut "gengsi" sering menjadi motivasi dalam memperoleh produk. Dijumpai juga gejala sosio psikologis berupa keinginan meniru sehingga remaja berlomba-lomba yang satu ingin lebih baik dari yang lain. Dalam pencarian identitas diri para remaja tidak semua menemukan identitas yang sebenarnya, tetapi mayoritas para remaja ketika dalam proses pencarian identitas dirinya, mereka lebih mengikuti apa saja yang dilakukan orang lain mulai dari gaya berpakaian, tutur kata, perbuatan, sifat dan sikap tanpa memfilternya sehingga mereka hanya sekedar ikutikutan dan tidak peduli itu baik atau buruk.

Atmadji mengemukakan bahwa penduduk Indonesia cenderung lebih suka mengkonsumsi produk inpor dan menghindari pemakaian produk dalam negeri. Ini terjadi karena kebanyakan konsumen melakukan kegiatan konsumsinya demi penentuan identitas diri mereka. Mereka mengejar tren yang sedang tumbuh di 
masyarakat dan status diri tersebut hanya bisa ditemukan dengan mengkonsumsi banyak produk yang dianggap biasa mengangkat derajat identitas dirinya survei yang dilakukan oleh (Soegiono:2012) menemukan bahwa ada dua macam konsumen fanatik. Konsumen golongan pertama cenderung memilih produk impor karena produk impor dianggap memiliki kualitas yang terjami. Konsumen golongan kedua lebih fanatik dengan produk lokal karena mereka beranggapan bahwa produk lokal cenderung lebih murah, lebih mudah didapat dan lebih sesuai dengan kondisi masyarakat Indonesia.

Komitmen mencintai produk dalam negeri adalah perjanjian yang terikat dalam ikatan emosi yang mempengarui sikap positif tindakan perilaku seseorang terhadap loyalitas dalam dirinya dengan ungkapan perasaan yang dimiliki setiap manusia yang melibatkan komitmen, rasa persatuan, budi pekerti, untuk mengembangkan, menjaga dan memelihara apa yang dimiliki oleh diri sendiri, orang lain dan lingkungan, untuk memenuhi kebutuhan kehidupannya Indikatornya Menanamkan komitmen cinta produk dalam negeri, Cara mengembangkan produk dalam negeri, Mengkonsumsi produk dalam negeri, Memperkenalkan produk dalam negeri, Manfaat cintai produk dalam negeri, Menjaga dan melestarikan produk dalam negeri.

\section{METODE PENELITIAN}

Lokasi penelitian adalah SMK AL-basyariah Bogor yang beralamat Jl. Raya Pabuaran Gg. Langgar Ds. Rawa Panjang Kec. Bojonggede Bogor. Penelitian di mulai bulan Juli-September selama 3 bulan. Penelitian ini adalah menggunakan metode kuantitatif dengan pendekatan korelasional yaitu mencari sejauh mana hubungan yang saling berkaitan. (Pudjiastuti : 2016), Populasi penelitian adalah siswa SMK Al-Basyariah Bogor sejumlah 106 siswa, sedangkan pengumpulan data dalam penelitian ini adalah dengan menggunakan tes pilihan ganda untuk variabel X1 (pemahaman siswa tentang entrepreneurship), angket skala perilaku untuk X2 (gaya hidup konsumtif), sedangkan pada variabel Y komitmen cinta produk dalam negeri juga menggunakan angket skala perilaku. Teknik analisis data yang digunakan dalam penelitian ini adalah korelasi product moment.

\section{HASIL DAN PEMBAHASAN}

Berdasarkan hasil penelitian yang dilakukan, maka hasil penelitian disajikan dalam bentuk penyajian data yang sesuai dengan hasil pengukuran yang dilakukan. Nilai yang merupakan hasil tes Pemahaman siswa tentang entreprenuership (X1). Disimpulkan bahwa dari 106 SMK Al-Basyariah Bogor menunjukkan bawah ada 10 siswa (9,43\%) memiliki kategori 12-13, dan 18 siswa $(16,98 \%)$ memilki kategori 18-19, dan 11 siswa (10,38 \%) memiliki kategori 2021, dan 27 siswa $(25,47 \%)$ memiliki kategori 22-23, dan 18 orang siswa $(16,98 \%)$ memiliki kategori 24-25, dan 16 siswa (15,09\%) memiliki kategori 26-27 dan 6 siswa $(5,66) \%)$ memiliki kategori 28-29.

Nilai pada hasil pengisian kuesioner Gaya Hidup Konsumtif (X2). Disimpulkan bahwa dari 106 SMK Al Basyariah Bogor menunjukkan bawah ada 4 siswa $(3,77 \%)$ memiliki kategori 40-47, dan 5 siswa (4,72\%) memiliki kategori 48-55, dan 4 siswa $(4,72 \%)$ memiliki kategori 56-63, dan 18 siswa $(16,98 \%)$ memiliki kategori 64-71, dan 22 siswa (20,75\%) memiliki kategori 72-79 dan 
22 siswa $(20,75 \%)$ memiliki kategori $80-87$ dan 13 siswa (12,26\%) memiliki kategori 88-95 dan 18 siswa $(16,98)$ memiliki kategori 95-103.

Nilai pada hasil Komitmen Cinta Produk dalam negeri (Y). Disimpulkan bahwa dari 106 sisw SMK Al-Basyariah Bogor menunjukkan bawah ada 9 orang siswa $(8,49 \%)$ memiliki kategori $46-53$, dan 4 orang siswa $(3,77 \%)$ memiliki kategori 54-61, dan 9 orang siswa $(8,49 \%)$ memiliki kategori 62-69 dan 9 orang siswa $(8,49 \%)$ memiliki kategori $70-77$, dan 44 orang siswa $(41,51 \%)$ memiliki kategori 78-85, dan 12 siswa $(11,23 \%)$ memiliki kategori 86-93 dan 19 siswa (17,92\%) memiliki kategori 94-101. Untuk lebih jelasnya lagi dapat dilihat pada grafik berikut:

Tabel 1

Uji Homogenitas Varians

\begin{tabular}{|c|l|c|c|c|}
\hline No & \multicolumn{1}{|c|}{ Variabel } & $\mathrm{X}^{2}$ hitung & $\mathrm{X}^{2}$ tabel & Keterangan \\
\hline 1 & $\begin{array}{l}\text { Pemahaman siswa tentang } \\
\text { entreprenurship (X1) }\end{array}$ & 6,5302 & 9,4877 & Normal \\
\hline 2 & $\begin{array}{l}\text { Gaya Hidup konsumtif } \\
\left(\mathrm{X}_{2}\right)\end{array}$ & 7,0731 & 9,4877 & Normal \\
\hline 3 & $\begin{array}{l}\text { Komitmen Cinta produk } \\
\text { dalam negeri (Y) }\end{array}$ & 7,1418 & 9,4877 & Normal \\
\hline
\end{tabular}

Dari hasil perhitungan yang menggunakn uji Barlet, variabel pemahaman siswa tentang entreprenurship X2 hitung sebesar 6,5302. Variabel gaya hidup konsumtif X2 hitung sebesar 7,0731. Variabel komitmen cinta produk dalam negeri X2 hitung sebesar 7,1418, sedangkan untuk X2 tabel adalah 9,4877 maka X2 hitung $<\mathrm{X} 2$ tabel dinyatakan ketiga variabel mempunyai data homongen.

Tabel 2

Uji Linieritas Regresi

\begin{tabular}{|c|l|c|c|c|}
\hline No & \multicolumn{1}{|c|}{ Variabel } & $\mathrm{F}_{\text {hitung }}$ & $\mathrm{F}_{\text {tabel }}$ & Ket \\
\hline 1 & $\begin{array}{l}\text { Pemahaman siswa tentang } \\
\text { entrepreneurship(X1) dengan Komitmen } \\
\text { Cinta Produk dalam Negeri (Y) }\end{array}$ & 4,000 & 2,04 & Linear \\
\hline 2 & $\begin{array}{l}\text { Gaya Hidup Konsumtif }\left(\mathrm{X}_{2}\right) \text { dengan } \\
\text { Komitmen Cinta Produk dalam Negeri } \\
(Y)\end{array}$ & 21,917 & 2,04 & Linear \\
\hline 3 & $\begin{array}{l}\text { Pemahaman Siswa tentang } \\
\text { entrepreneurship (X }) \text { Dan Gaya hidup } \\
\text { Konsumtif }\left(\mathrm{X}_{2}\right) \text { Bersama-Sama } \\
\text { Mempengaruhi Dengan Komitmen Cinta } \\
\text { Produk dalam Negri (Y) }\end{array}$ & 1,202 & 2,04 & Linear \\
\hline
\end{tabular}

Hasil Uji linieritas regresi variabel pemahaman siswa tentang entrepreurship dengan komitmen cinta produk dalam negeri diperoleh hasil $\mathrm{F}$ hitung 4,000, dan variabel gaya hidup konsumtif dengan komitmen cinta produk dalam negeri diperoleh $\mathrm{F}$ hitung sebesar 21,917 dan pemahaman siswa tentang entreprenurship dan gaya hidup konsumtif dengan komitemen cinta produk dalam negeri diperoleh $\mathrm{F}$ hitung 1,202, kemudian dikonsultaiskan kepada $\mathrm{F}$ tabel sebesar $2,04(\alpha=0,05)$ dinyatakan ketiga variabel tersebut linier / signifikan 
Tabel 3

Uji-t

\begin{tabular}{|c|l|c|c|c|}
\hline No & \multicolumn{1}{|c|}{ Variabel } & $\mathrm{t}_{\text {hitung }}$ & $\mathrm{t}_{\text {tabel }}$ & Ket \\
\hline 1 & $\begin{array}{l}\text { Pemahaman siswa tentang } \\
\text { entrepreneurship }\left(\mathrm{X}_{1}\right) \text { dengan } \\
\text { Komitmen cinta produk dalam negeri } \\
(\mathrm{Y})\end{array}$ & 3,5641 & 1,983 & Signifikan \\
\hline 2 & $\begin{array}{l}\text { Gaya hidup konsumtof }\left(\mathrm{X}_{2}\right) \text { dengan } \\
\text { Komitmen cinta produk dalam } \\
\text { Negeri (Y) }\end{array}$ & 35,469 & 1,983 & Signifikan \\
\hline
\end{tabular}

Hasil perhitungan uji-t variabel $\mathrm{X} 1$ terhadap $\mathrm{Y}$ diperoleh $\mathrm{t}$ hitung sebesar 3,5641, variabel X2 terhadap Y diperoleh t hitung sebesar 35,469, variabel $\mathrm{X} 1$ dan $\mathrm{X} 2$, hasil tersebut dikonsultasikan dengan $\mathrm{t}$ tabel sebesar 1,983 dinyatakan singnifikan karena t hitung $>\mathrm{t}$ tabel.

Tabel 4

Uji-F

\begin{tabular}{|c|l|c|c|c|}
\hline No & \multicolumn{1}{|c|}{ Variabel } & $t_{\text {hitung }}$ & $t_{\text {tabel }}$ & Ket \\
\hline 1 & $\begin{array}{l}\text { Pemahaman siswa tentang } \\
\left.\text { entrepreneurship (X } \text { X }_{1}\right) \text { dan gaya hidup } \\
\text { konsumtif ( X2) dengan Komitmen } \\
\text { cinta produk dalam negeri (Y) }\end{array}$ & 143,864 & 1,983 & Signifikan \\
\hline
\end{tabular}

Hasil uji $\mathrm{F}$ menyatakan bahwa variabel pemahaman sisiwa tentang entreprenurship dan gaya hidup konsumtif dengan variabel komitmen cinta produk dalam negeri diperoleh nilai $\mathrm{F}$ hitung sebesar 143,864 dan dinayatakan singnifikan karena f hitung > dari pada f tabel.

Pengujian hipotesis dilakukan dengan korelasi Product Moment dari hasil perhitungan dapat disimpulkan; (1) Terdapat hubungan positif yang sangat signifikan antara pemahaman siswa tentang entrepreneurship dan gaya hidup konsumtif dengan komitmen cinta produk dalam negeri koefisien korelasi $\left(\mathrm{r}_{\mathrm{y} 1}\right)$ sebesar 0,03299 $(\alpha=0,05)$ didukung dengan persamaan regresi antara kedua variabel adalah $\hat{\mathrm{Y}}=2102,17+93,877 \mathrm{X} 1$, yang berarti setiap perubahan satu tingkat pemahaman siswa tentang entrepreneurship akan dapat mengakibatkan terjadinya perubahan komitmen cinta produk dalam negeri pada siswa sebesar 93,877 pada konstanta 2102,17. Kontribusi pemahaman tentang entreprenuership sebesar $10,88 \%\left(\mathrm{r}_{\mathrm{y} 1}\right)$. (2) Terdapat hubungan positif yang sangat signifikan antara gaya hidup konsumtif dengan komitmen cinta produlk dalam negeri dengan koefisien korelasi $\left(\mathrm{r}_{\mathrm{y} 2}\right)$ sebesar 0,9611 $(\alpha=0,05)$ didukung dengan persamaan regresi antara kedua variabel tersebut adalah $\hat{\mathrm{Y}}=2330,46+29,3431 \mathrm{X}_{2}$, yang berarti setiap perubahan satu unit gaya hidup konsumtif akan dapat mengakibatkan terjadinya perubahan gaya hidup konsumtif pada siswa sebesar 29,3431 pada kontanta 233,46. Kontribusi gaya hidup konsumtif dengan komitmen cinta produk dalam negeri sebesar 92,36\% $\left(\mathrm{r}_{\mathrm{y} 2}\right)$. Terdapat hubungan positif yang sangat signifikan antara pemahaman siswa tentang entrepreuership dan gaya hidup konsumtif bersama-sama dengan pelestarian budaya bangsa 
dengan koefisien korelasi $\left(\mathrm{R}_{\mathrm{y} 12}\right)$ sebesar 0,9614 $(\alpha=0,05)$ didukung dengan persamaan regresi ganda antaar kedua variabel bebas dengan variabel terikat adalah $\hat{Y}=9,033+(-0,0826) \mathrm{X}_{1}-0,092151 \mathrm{X}_{2}$. Kontribusi pemahaman siswa tentang entrepreuership dan gaya hidup konsumtif dengan komitmen cinta produk dalam negeri sebesar $92,42 \%\left(\mathrm{R}_{\mathrm{y} 12}\right)$.

\section{KESIMPULAN}

Berdasarkan pada hasil analisis penelitian dan pembahasan, maka dapat disimpulkan beberapa hal sesuai dengan permasalahan-permasalahan dalam penelitian ini. Adapun simpulan tersebut adalah sebagai berikut :

1. Dari hasil pengisian tes pemahaman siswa tentang entreprenuership $\left(X_{1}\right)$. Disimpulkan bahwa dari 106 Al-Basyariah Bogor menunjukkan bawah ada 10 siswa $(9,43 \%)$ memiliki kategori 12 - 13, dan 18 siswa ( $16,98 \%$ ) memilki kategori 18 - 19 ,dan 11 siswa ( 10,38 \% ) memiliki kategori 20 21 ,dan 27 siswa ( $25,47 \%$ ) memiliki kategori $22-23$, dan 18 orang siswa $(16,98 \%)$ memiliki kategori 24 -25,dan 16 siswa ( $15,09 \%)$ memiliki kategori 26-27 dan 6 siswa ( 5,66)\%) memiliki kategori 28-29,. Pemahaman siswa tentang entreprneurship dengan materi kewirausahaan juga terdapat hubungan sebesar 10,88\% dengan keberhasilan dengan komitmen cinta produk dalam negeri. Berorientasi pada hasil tersebut, keberhasilan pemahaman siswa tentang entrepreneurship pada materi kewirausahaan atas $89,12 \%$ ditentukan oleh aspek lain di luar yang sangat besar. Bisa dikatakan pemahaman siswa tentang entreprenuership siswa pada materi kewirausahaan kurang dari $1 / 2$ (setengah) yang bisa dinyatakan memiliki hubungan antara pemahaman siswa tentang entreprenuership dengan komitmen cinta produk dalam negeri.

2. Dari hasil pengisian kuesioner Gaya hidup konsumtif $\left(\mathrm{X}_{2}\right)$. Disimpulkan bahwa dari 106 SMK AL-Basyariah Bogor menunjukkan bawah ada 4 siswa $(3,77 \%)$ memiliki kategori 40 - 47, dan 5 siswa $(4,72 \%)$ memiliki kategori 48 - 55, dan 4 siswa (4,72\%) memiliki kategori 56 - 63, dan 18 siswa (16,98\%) memiliki kategori 64 - 71, dan 22 siswa ( 20,75\%) memiliki kategori 72 - 79 dan 22 siswa $(20,75 \%)$ memiliki kategori 8087 dan 13 siswa ( $12,26 \%$ ) memiliki kategori 88 - 95 dan 18 siswa ( 16,98) memiliki kategori 95 - 103. Gaya hidup konsumtif juga terdapat hubungan sebesar 92,36\% dengan keberhasilan komitmen cinta produk dalam negeri. Berorientasi pada hasil tersebut, gaya hidup konsumtif 7,64\% ditentukan oleh aspek lain di luar. Bisa dikatakan gaya hidup konsumtif dengan komitmen cinta produk dalam negeri lebih dari $1 / 2$ (setengah) yang bisa dinyatakan memiliki hubungan antara gaya hidup konsumtif dengan komitmen cinta produk dalam negeri.

Ada korelasi hubungan signifikan antara pemahaman siswa tentang entreprenurship dan gaya hidup konsumtif dengan komitmen cinta produk dalam negeri dilakukan dengan analisis korelasi ganda. Hasil analisis untuk mengetahui korelasi hubungan signifikan antara Pemahaman siswa tentang entrepreneurship dan gaya hiudp konsumtif dengan komitmen cinta produk dalam negeri, maka diperoleh diperoleh $\mathrm{r}_{\text {hitung }}$ sebesar 0,9614. Hasil tersebut kemudian dikonsultasikan dengan $r_{\text {tabel }}$ sebesar 0,1909 $(\alpha=0,05$ dan $\mathrm{N}=$ 
106). Hasil konsultasi tersebut menunjukan bahwa $r_{\text {hitung }} \geq r_{\text {tabel }}, \quad 0,9614 \geq$ 0,1909 .

3. . Hal ini menunjukan bahwa ada hubungan signifikan antara pemahaman siswa tentang entrepreneurship dan gaya hidup konsumtif dengan komitmen cinta produk dalam negeri, jumlah 106 siswa SMK Al-Basyariah Bogor. Dari perhitungan koefisien determinan (KD) diketahui bahwa hubungan pemahaman siswa tentang entrepreneurship dan gaya hidup konsumtif terhadap komitmen cinta produk dalam negeri adalah sebesar $92,42 \%$ sedangkan $7,58 \%$ ditentukan oleh faktor lain.

\section{REFERENSI}

Aprilia \& Hartono, (2013), "Analisis Sosiologi Perilaku Konsumtif Mahasiswa" Universitas FISIP Lampung, jurnal Sosiologi h. 72-86.

Atmadji,E Analisis Infor Indonesia. Jurnal ekonomi Pembagunan Vol 9No.1 Juni 33-46

Desri Arweh kompetensi "guru dan mutu pendidikan "Jakarta 2016 Al wasat publising House.

Husaini, Usman, (2009), Manajemen: Teori, Praktik dan Riset Pendidikan, Jakarta: PT. Bumi Aksara.

Kartodihardjo. S,(1995), “Konsumerisme dan perlindungan konsumen”, akademika NO.1 tahun XIII th 1995 Surakarta Muhammdiyah University press.

Mubarok Zahid, MEI, Dr. Suharto, M,Si,.MM “ Pendidikan kewirausahandan kemandirian anak" Pustaka Amma Alamia 2020 Bogor

Pujiastuti, SR, 2016, Penelitian Pendidikan, Depok Fatma Aji.

Pudjiastuti, Sri Rahayu (2019), "Membudayakan Entrepreneurship di Era 4.0",Sintesa: Jurnal Ilmu Pendidikan 14(1), h.12-18

Pudjiastuti,S,R , Safitri.R , Sutisna.M and Hadi.N ,(2020), Utilization of Forest Natural Resource Potentials, Especially Wood, to Realize Independence of Regional Development, Jour of Adv Research in Dynamical \& Control Systems, 12 (1). Pg.1720-1724. DOI:10.5373/JARDCS/V1212/S20201212.

Riayanti, Prihatin Dwi, (2003) Enterpreneurship dari sudut pandang Psikologi Kepribadian, Jakarta: Grasindo.

Sutisna,(2008), Perilaku Konsumen dan Komunikasi Pemasaran.

Setiadi, Nugroho J.(2010), Perilaku Konsumen, Kencana, Jakarta.

Sugiono (2012), Metode penelitian Bisnis, Alpabeta, Jakarta. 